\title{
Antagonistic Effect of the Lactic Bacteria Isolated from the Camel Milk on Staphylococcus aureus in Yoghourt Manufacturing
}

\author{
Belkis Abdessemed ${ }^{1, *}$ and Arezki Bitam ${ }^{1,2}$ \\ ${ }^{1}$ Département de Biologie, Université de Blida, Algérie \\ ${ }^{2}$ Département de Nutrition Humaine, Ecole Nationale Supérieure Agronomique, El-Harrach, Algérie
}

\begin{abstract}
This paper deals with the lactic bacteria found in the raw camel milk producing antibacterial substances. Samples of milk were obtained from female camels of herds from nomads living in the south of Algeria. The antibacterial activity of the bacteria was tested on Staphylococcus aureus strains and to highlight this activity in a yoghourt for therapeutic purpose.

Among the seven (07) strains of lactic bacteria which were isolated from camel milk $L b$. fermentum (Lc17) presented the highest antagonistic effect on $S$. aureus. After incorporation in the yoghourt ,It was verified that there was no interaction between the lactic ferments of yoghourt and $L b$. fermentum and no modification of the acidity. However the realization of a yoghourt containing $\mathrm{Lb}$. fermentum with shown a total inhibition of Staphylococcus aureus to a load 5,87 log UFC compared to that of yoghourt made up exclusively of lactic leavens, after 4 hours of incubation in mixed culture.
\end{abstract}

Keywords: Antagonism, lactic bacteria, Therapeutic purpose, camel, Staphylococcus aureus, yoghourt.

\section{INTRODUCTION}

The lactic acid bacteria has received considerable interest because their antagonistic properties make them particularly useful as biological preservatives [1]. The microflora of bovine milk has been extensively studied, however that of camel milk, has received much less attention in te peer-reviewed literature [2].

Many strains of lactic bacteria are currently being studied to evaluate their utility in the prevention or cure of diseases associated with the consumption of yoghourt. Beneficial effects have been detected regarding: digestion of lactose [3], symptoms of diarrhea [4]. inflammatory bowel diseases [5] and, possibly, gastric ulcers [6] and the regulation of the blood lipid level [7].

\section{OBJECTIVES}

The aim of this work was isolating new strains of bacteria from camel milk able to inhibiting pathogenic bacteria such as Staphylococcus aureus and demonstrated this activity in dairy 'yogurt' for therapeutic purposes

\section{Isolation of Lactic Acid Bacteria from Camel Milk}

\section{Milk Collection}

Samples of raw camel milk coming from the Djelfa region (south of Algeria) were collected. Each one was

\footnotetext{
*Address correspondence to this author at the Département de Biologie, Université de Blida, Algérie; Tel: +213 25434 003; Fax:+213 4338 64;

E-mail: belkiss_ab@hotmail.fr
}

constituted by $150 \mathrm{ml}$ of milk collected directly from the breast of the animal.

Decimal dilutions were prepared using sterile Ringer solution. A volume of $0.1 \mathrm{ml}$ of each dilution was used for double layer surface plating on MRS medium, which was then incubated at $30^{\circ} \mathrm{C}$ and in the dark for $72 \mathrm{~h}$ [8]. The reference bacterial strain was Staphylococcus aureus ATCC 29213.

\section{Purification and Identification of Lactic Acid Bacteria}

The purification of the isolated bacteria was performed according to the method described [9]. Bacteria that showed a Gram positive stain and lacked catalase activity were separated for identification. They were submitted to a series of simple tests for preliminary identification: growth in MRS medium with addition of $\mathrm{NaCl}$, growth at different temperatures and search of the homo- or hetero-fermenting type by the classical method [10, 11].

\section{Demonstration of the Antagonistic Effect of Isolates Against Staphylococcus aureus}

The lactobacillus species were inoculated in tubes containing $9 \mathrm{ml}$ of MRS medium, which were incubated during $18 \mathrm{~h}$ at $30^{\circ} \mathrm{C}$.

Staphylococcus aureus ATCC 29213 was grown in Chapman broth and incubated for $18 \mathrm{~h}$ at $37^{\circ} \mathrm{C}$.

The surface of Petri dishes containing TSA medium was covered with a few milliliters of preliminary culture of Staphylococcus aureus strain and allowed to dry for 30 minutes at $37^{\circ} \mathrm{C}$.

(c) 2013 Lifescience Global 
Discs of blotting paper were soaked with the preliminary culture of lactic acid bacteria. They were left to dry and then placed on TSA media plates which, in turn, were allowed to dry for 30 minutes. Then they were left at $4^{\circ} \mathrm{C}$ for 4 hours to ensure the diffusion of the substances responsible for the interaction and finally incubated at $37^{\circ} \mathrm{C}$ for 24 hours.

The inhibition of the indicator strain results in the formation of clear zones around the disks, whose diameter (in $\mathrm{mm}$ ) is measured from the periphery of the disc [12].

\section{Effect of the Camel Milk Isolates on the Yoghourt Ferments}

Two flasks with a volume of $110 \mathrm{ml}$ of reconstituted milk, which had been sterilized in the autoclave at $120^{\circ} \mathrm{C}$ for 20 minutes, were inoculated with the strains of Lactobacillus delbrueckii subspecies bulgaricus and Streptococcus thermophilus, approximately $0.1023 \mathrm{~g} / \mathrm{I}$ of milk[16] . A volume of $1 \mathrm{ml}$ of camel milk isolates that showed strong inhibitory activity (approximately 5.87 log CFU / ml) against Staphylococcus aureus was added to one of the two bottles (bottle 1). Both flasks were incubated at $44^{\circ} \mathrm{C}$ for $4 \mathrm{~h}$.

\section{Growth Kinetics}

Sampling at increasing time intervals $(1 \mathrm{~h}, 2 \mathrm{~h}, 3 \mathrm{~h}$, 4h) was followed by the preparation of decimal dilutions in Ringer solution. Then $0.1 \mathrm{ml}$ of the appropriate dilution was plated on MRS medium for enumeration of Lactobacillus delbrueckii subspecies bulgaricus ferment and M17 for Streptococcus thermophilus ferment count.

After studying the characteristics that differentiate the species of lactic acid bacteria (isolates of camel milk and yoghourt ferment Lactobacillus delbrueckii subspecies bulgaricus) belonging to the same genus Lactobacillus, growth in the presence of $6.5 \% \mathrm{NaCl}$ was shown specific for the isolate but not for the lactic ferment of the yoghourt Figure 1.

In order to eliminate any confusion, the count of camel milk isolate was performed on MRS medium with

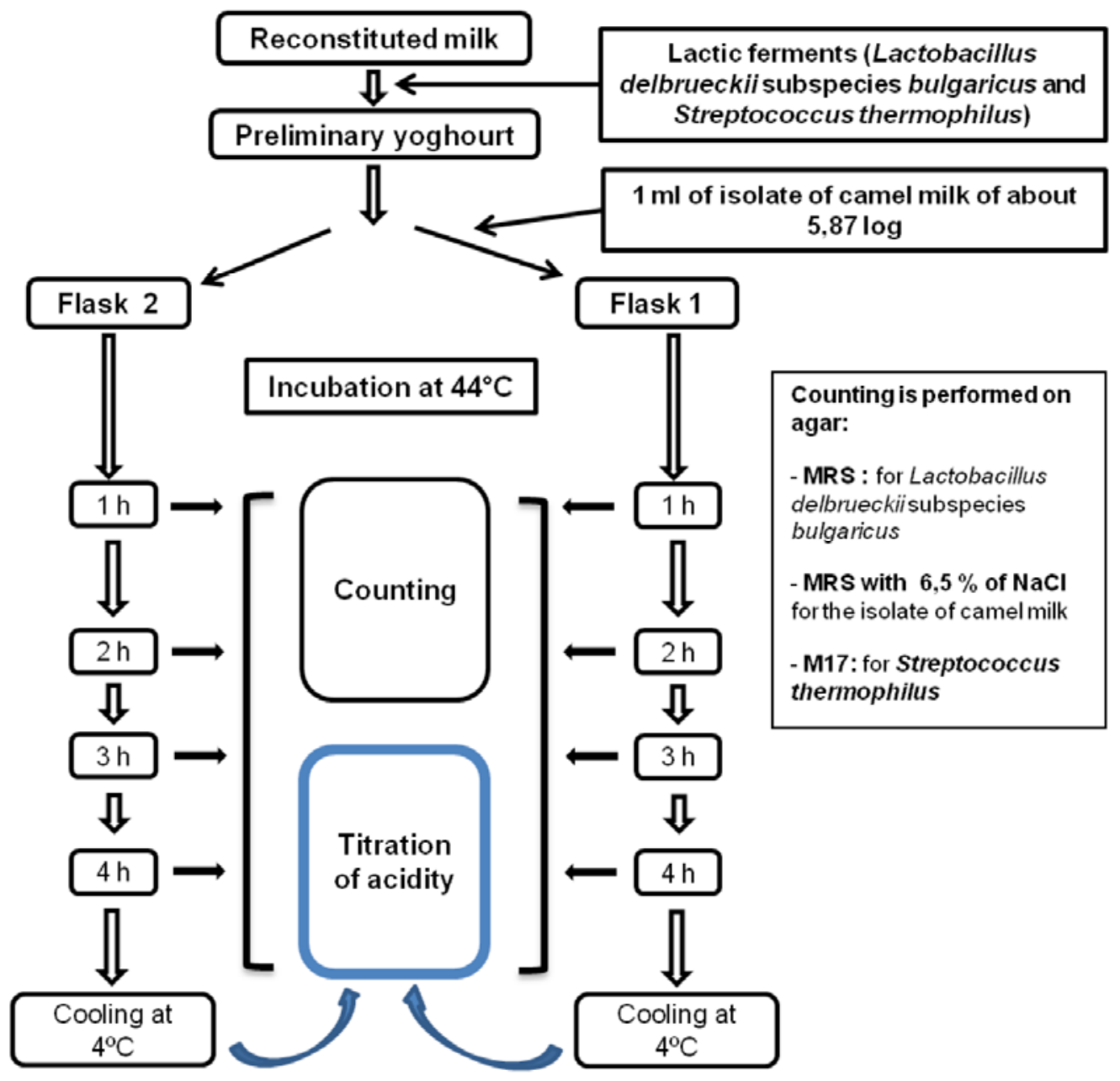

Figure 1: Experimental proceeding for the preparation of a yoghourt to which the isolate of camel milk. 
addition of $6.5 \% \mathrm{NaCl}$. The acidity produced by pure strains was assessed by titration, sampling $10 \mathrm{ml}$ from each bottle [13].

\section{Effect of the Camel Milk Isolates on the Behavior of Staphylococcus aureus in the Yoghourt}

\section{Preliminary Culture Preparation}

With each isolate of camel milk and Staphylococcus aureus were inoculated $10 \mathrm{ml}$ of sterile skim milk. The preliminary cultures were prepared by incubation at $30^{\circ} \mathrm{C}$ until coagulation.

\section{Preparation of the Preliminary Yoghourt}

The preliminary yoghourt was prepared from reconstituted milk sterilized by autoclaving at $120^{\circ} \mathrm{C}$ for 20 minutes and inoculated with $0.01125 \mathrm{~g} / \mathrm{ml}$ of lyophilized ferments.

The preliminary yoghourt was then dosed in 2 bottles:

- Bottle 1 was inoculated with $1 \mathrm{ml}$ of Staphylococcus aureus from about 5.05 log CFU / $\mathrm{ml}$.
- Bottle 2 was inoculated with $1 \mathrm{ml}$ of Staphylococcus aureus from about 5.05 log CFU / $\mathrm{ml}$ and $1 \mathrm{ml}$ of isolates of camel milk approximately 5.87 log CFU / $\mathrm{ml}$.

Both flasks were incubated at the same time at $37^{\circ} \mathrm{C}$ for $5 \mathrm{~h}$ to achieve maximum growth of Staphylococcus aureus.

Samples were taken at regular intervals $(1 \mathrm{~h}, 2 \mathrm{~h}, 3 \mathrm{~h}$, $4 \mathrm{~h}, 5 \mathrm{~h})$ and decimal dilutions $\left(10^{-1}\right.$ to $\left.10^{-4}\right)$ from the bottles were performed in order to make a count of Staphylococcus aureus on medium Chapman, which was then incubated at $37^{\circ} \mathrm{C}$ for $24 \mathrm{~h}$.

Furthermore $10 \mathrm{ml}$ extractions were performed to measure pH Figure 2.

\section{RESULTS}

\section{Characterization of Isolates}

The physiological and biochemical characteristics of the isolates are shown in the table below Figure 3 .

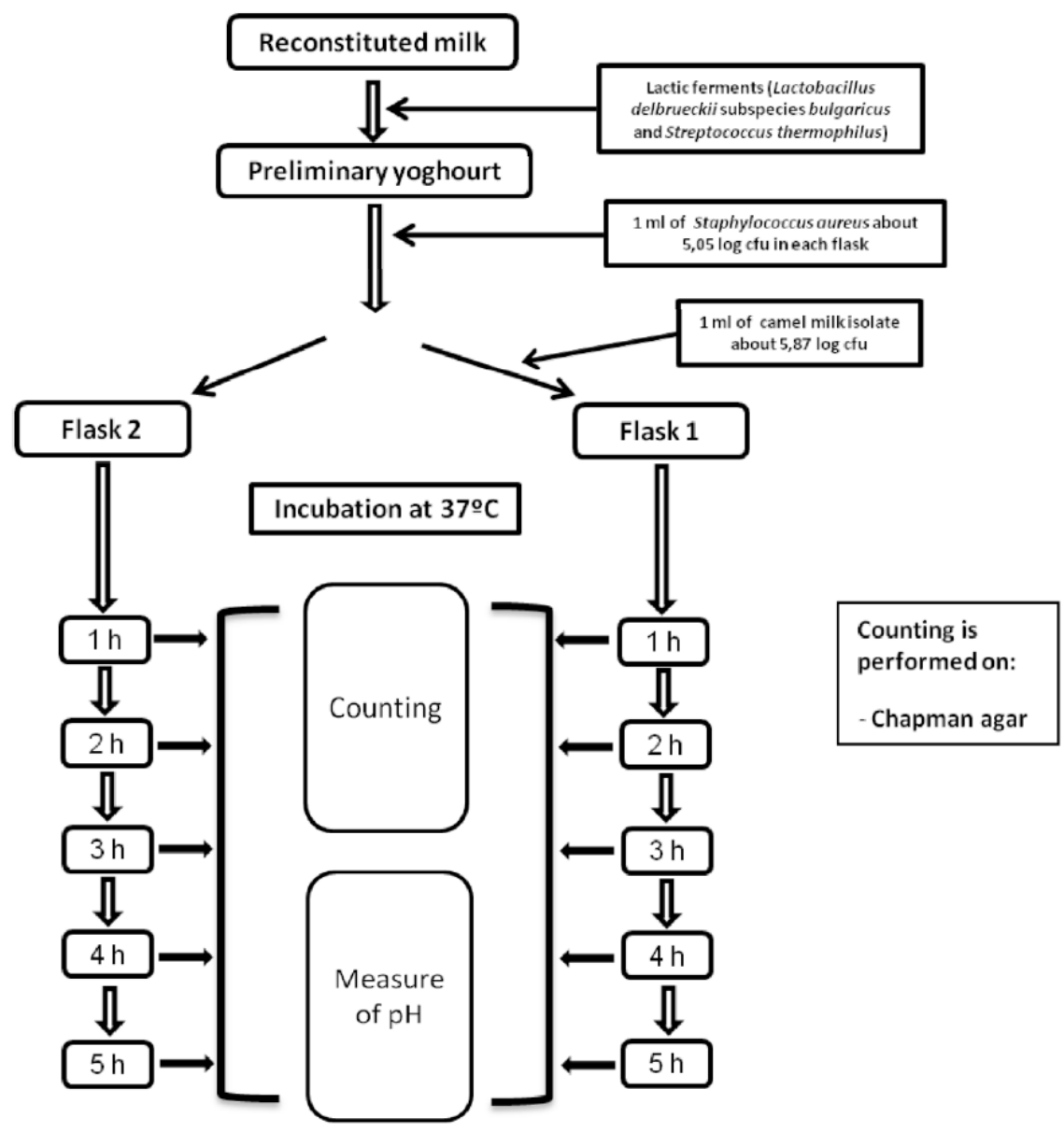

Figure 2: Diagram showing the preparation of a contaminated experimental yoghourt. 


\begin{tabular}{|c|c|c|c|c|c|c|c|c|}
\hline \multirow{2}{*}{\multicolumn{2}{|c|}{ Characteristic }} & \multicolumn{7}{|c|}{ Isolate } \\
\hline & & Lc2 & Lc3 & Lc4 & Lc7 & Lc16 & Lc17 & Lc22 \\
\hline \multicolumn{2}{|l|}{ Gram } & + & + & + & + & + & + & + \\
\hline \multicolumn{2}{|c|}{ Catalase } & - & - & - & - & - & - & - \\
\hline \multicolumn{2}{|c|}{ Morphology } & bacillus & bacillus & bacillus & bacillus & bacillus & bacillus & bacillus \\
\hline \multicolumn{2}{|c|}{$\mathrm{CO}_{2}$ on glucose } & - & - & + & - & + & + & - \\
\hline \multicolumn{2}{|c|}{ Growth at $45^{\circ} \mathrm{C}$} & + & + & + & + & + & + & - \\
\hline \multicolumn{2}{|c|}{ Growth at $10^{\circ} \mathrm{C}$} & - & - & + & - & + & + & + \\
\hline \multirow{3}{*}{ Growth with $\mathrm{NaCl}$} & $2 \%$ & + & + & + & + & + & + & + \\
\hline & $3 \%$ & + & + & + & + & + & + & + \\
\hline & $6,5 \%$ & + & + & + & + & + & + & + \\
\hline \multicolumn{2}{|l|}{$\mathrm{ADH}$} & - & - & - & + & + & + & + \\
\hline \multicolumn{2}{|c|}{ Esculine hydrolysis } & + & - & - & - & - & - & + \\
\hline \multicolumn{2}{|c|}{ Survival at $60^{\circ} \mathrm{C} / 30$ minutes } & + & + & + & + & - & + & + \\
\hline \multicolumn{2}{|c|}{ Glucose } & + & - & - & + & $+/-$ & + & $+/-$ \\
\hline \multicolumn{2}{|c|}{ Raffinose } & + & - & - & + & + & + & + \\
\hline \multicolumn{2}{|c|}{ Lactose } & + & + & - & + & + & + & + \\
\hline \multicolumn{2}{|c|}{ Cellubiose } & + & - & - & + & + & + & + \\
\hline \multicolumn{2}{|c|}{ Mannitol } & + & - & - & + & + & + & + \\
\hline \multicolumn{2}{|c|}{ Arabinose } & + & - & - & + & + & + & + \\
\hline \multicolumn{2}{|l|}{ Xylose } & - & - & - & + & - & + & + \\
\hline
\end{tabular}

Figure 3: Physiological and biochemical characteristics of the isolates from camel milk.

Among the 23 strains isolated from camel milk, 7 isolates were taken into account, all being Gram +, motionless, catalase negative and possessing bacillary form.

Strains LC4, LC16, Lc17 and Lc22 of Lactobacillus are classified within the group Betabacterium because they produce $\mathrm{CO}_{2}$ on glycoside medium.

Strain LC4 shows growth at $10^{\circ} \mathrm{C}$ and is close to the species Lactobacillus viridiscens.

Strain LC16 develops at $45^{\circ} \mathrm{C}$ and ferments arabinose and raffinose, being close to the species Lactobacillus buchneri, while Lc17 hydrolyzes arginine and is close to the species Lactobacillus fermentum.

The streptobacterium group, which differs from the preceding one because there is no production of gas, is represented by strain Lc22, which grows at $10^{\circ} \mathrm{C}$ but not at $45^{\circ} \mathrm{C}$.

Strain Lc22 ferments the group of sugars which were tested and is close to the species Lactobacillus plantarum.
Strains LC2, LC3 and LC7 grow at $45^{\circ} \mathrm{C}$ but not at $10^{\circ} \mathrm{C}$ and do not produce $\mathrm{CO}_{2}$, and thus they are classified into the group Thermobacterium.

Strain Lc2 ferments the raffinose, hydrolyzes esculin and is close to Lactobacillus acidophilus, while strain Lc3 ferments lactose and is close to the species Lactobacillus helveticus.

Strain Lc77 hydrolyzes arginine and is close to the species Lactobacillus delbrueckii subsp lactis.

The large number of isolates which were obtained can be explained because the bacteria were incubated for $5,7,9$ and 16 days.

\section{Antagonistic Effect of Camel Milk Isolates on Staphylococcus aureus}

The diameter registered for the inhibition zones varied from $07 \mathrm{~mm}$ (strain Lc2 showed the lowest activity) to $13 \mathrm{~mm}$ (the highest activity was recorded for strain Lc17) (Figure 4).

Strain (LC17), which has shown a strong inhibitory activity against Staphylococcus aureus, which is similar 


\begin{tabular}{|c|c|c|}
\hline & Strain & TSA \\
\hline \hline Lc 2 & Lactobacillus acidophilus & 07 mm \\
\hline Lc 3 & Lactobacillus helveticus & mm \\
\hline Lc 4 & Lactobacillus viridiscens & $11 \mathrm{~mm}$ (nhibition) \\
\hline Lc 7 & Lactobacillus delbrueckii subsp lactis & $11 \mathrm{~mm}$ \\
\hline Lc 16 & Lactobacillus buchneri & $13 \mathrm{~mm}$ \\
\hline Lc 17 & Lactobacillus fermentum & $10 \mathrm{~mm}$ \\
\hline Lc 22 & Lactobacillus plantarum & \\
\hline
\end{tabular}

Figure 4: Diameter of the inhibition zones of the 7 isolates from the camel milk in front of Staphylococcus aureus by the method of diffusion on TSA medium.

to the species Lactobacillus fermentum (biochemical identification) is the one that was used in the following experiment.

\section{Interactions between Lactobacillus fermentum and Yoghourt Ferments}

\section{Count of Yoghourt Ferment and Lactobacillus fermentum after 4 Hours in Mixed Culture}

The growth of lactic acid bacteria was stationary after 4 hours of incubation both in camel milk (Lactobacillus fermentum) and in the yoghourt (Lactobacillus fermentum and Lactobacillus delbrueckii subspecies bulgaricus and Streptococcus thermophilus) Figure 5.

The number of lactic acid bacteria varied between 7.00 and $5.17 \log \mathrm{CFU} / \mathrm{ml}$.

The addition of Lactobacillus fermentum isolated from camel milk has no inhibitory effect against yoghourt ferments (Lactobacillus delbrueckii subspecies bulgaricus and Streptococcus thermophilus).

\section{Biochemical Analysis}

After $4 \mathrm{~h}$ of incubation the acidity increased significantly, reaching $58^{\circ} \mathrm{D}$ in the yoghourt which was inoculated with Lactobacillus fermentum Figure 6. After cooling, as a means for interrupting fermentation, the acidity values of both types complied with AFNOR standards [16].

\section{Effect of Lactobacillus fermentum on the Behavior of Staphylococcus aureus in the Yoghourt}

It was not detected any antagonist effect on Staphylococcus aureus which was incorporated at about $5.05 \mathrm{cfu} / \mathrm{ml}$ in bottle 1 (yoghourt without Lactobacillus fermentum). By contrast, after addition of Lactobacillus fermentum, a decrease was detected after only 2 hours of incubation and after 4 hours there is a lack of growth of Staphylococcus aureus, which demonstrates the inhibitory effect of Lactobacillus fermentum Figure 7.

If a high burden of Staphylococcus aureus (> 5.5 log CFU / $\mathrm{ml}$ ) is introduced, the effect of Lactobacillus fermentum is not noticeable.

\section{Biochemical Analysis}

The $\mathrm{pH}$ is stable in both types of yoghourt during the 2 hours of incubation, afterwards, a sharper decrease of $\mathrm{pH}$ is detected for both types of yoghourt Figure 8.

The final $\mathrm{pH}$ is a little high, since it has a value of 5.2 in comparison with the $\mathrm{pH}$ of common yoghourt which is 4.34 . This is a consequence of the incubation

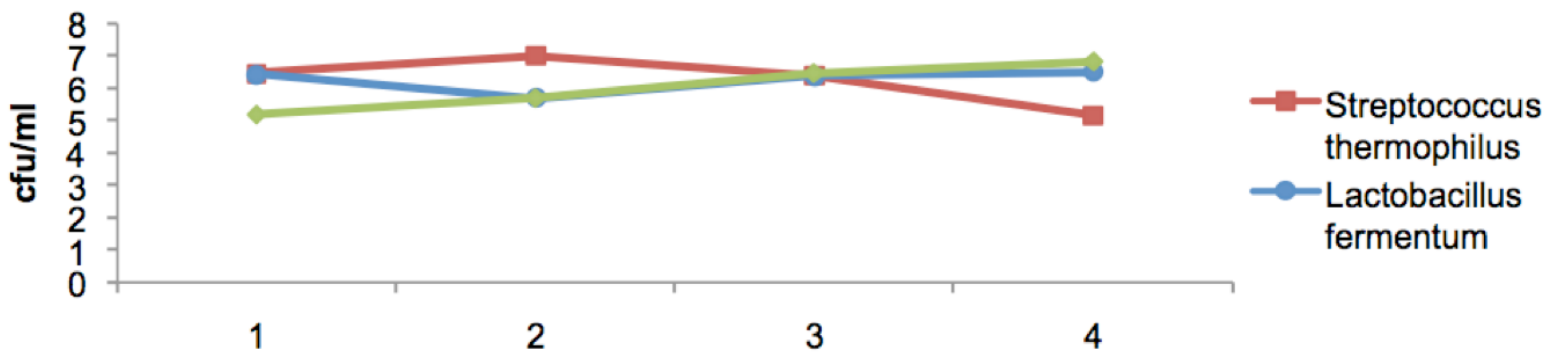

Figure 5: Growth of Lactobacillus fermentum, Lactobacillus delbrueckii subspecies bulgaricus and Streptococcus thermophilus in a mixed culture in the yoghourt. 


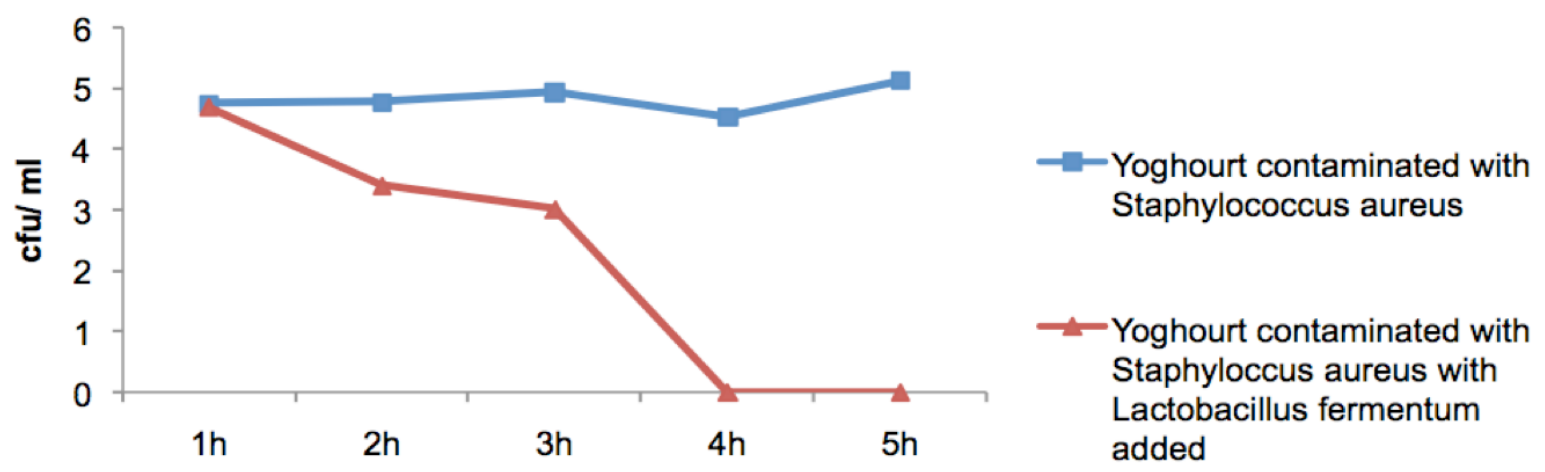

Figure 6: Growth of Staphylococcus aureus in an isolated and mixed culture with Lactobacillus fermentum.

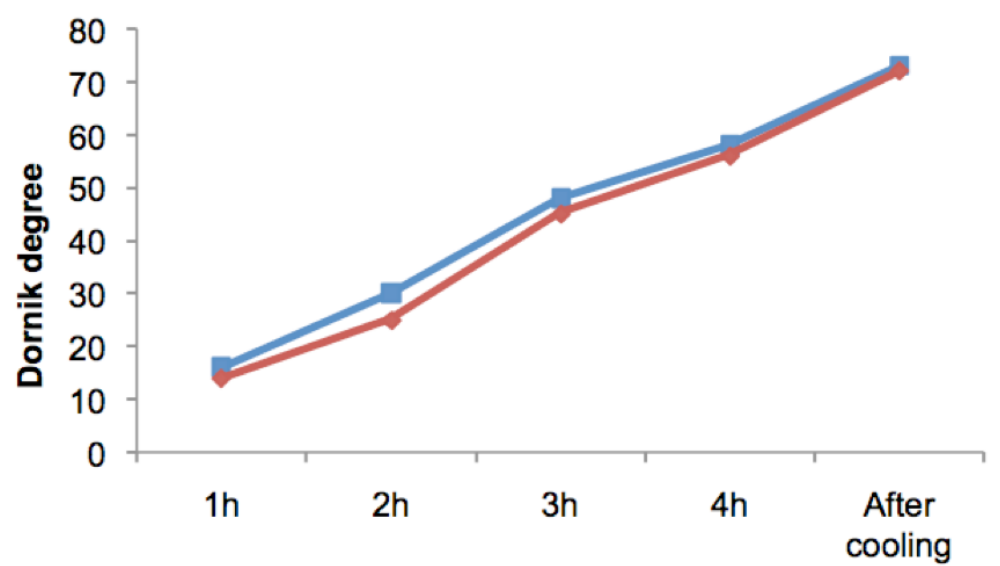

- -Yoghourt with Lactobacillus fermentum added

$\leadsto$ Yoghourt

Figure 7: Evolution of the acidity during the maturation of both types of yoghourt expressed in Dornik degrees.

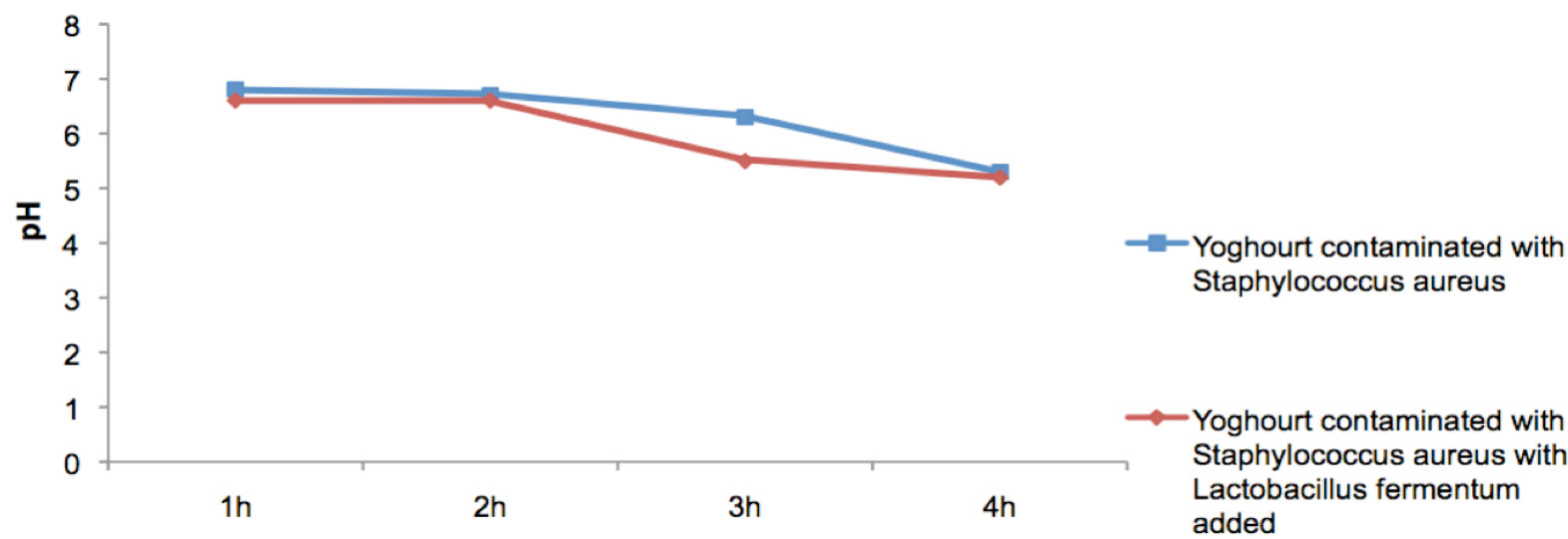

Figure 8: Evolution of pH during the maturation of the two types of yoghourt contaminated with Staphylococcus aureus.

temperature $\left(37^{\circ} \mathrm{C}\right)$, which is lower than the temperature of maturation of the yoghourt $\left(44^{\circ} \mathrm{C}\right)$.

\section{DISCUSSION}

The seven isolates were all Gram +, motionless and catalase negative, confirming the data of Gunter et al. [17].

The fermentation profile of the seven Lactobacillus isolates was compared with the reference strains as exposed in Bergey's key [15]. Significant differences were found. For example: Lactobacillus fermentum differs from the strain reference because of the fermentation of arabinose and mannitol.

The identified species Lactobacillus plantarum is only represented by the strain Lc22 while Lactobacillus strains isolated by Karam et al. [18] belong essentially to the species plantarum.

The addition of Lactobacillus fermentum isolated from camel milk has no inhibitory effect against yoghourt ferments (Lactobacillus delbrueckii 


\section{subspecies bulgaricus and Streptococcus thermophilus).}

The acidity of the yoghourt where Lactobacillus fermentum was added meets AFNOR standards. The decrease in the number of living cells of Staphylococcus aureus from the $3^{\text {rd }}$ hour of incubation in the presence of Lactobacillus fermentum shows the inhibitory effect of the latter. This result has been observed in the work of Mami et al., 2010 in some species of Lactobacillus on Staphylococcus aureus. The results show a total lack of Staphylococcus aureus in the presence of Lactobacillus fermentum after only 4 hours of incubation in mixed cultures, whereas this was only observed by Mami et al., 2010 after 72 hours.

The inhibitory effect of the Lactobacillus fermentum strain of Staphylococcus aureus at a concentration of up to $5.05 \log$ CFU is nil.

In any case, the inhibition of Staphylococcus aureus is not caused by $\mathrm{pH}$, because in the course of maturation the yoghourt contaminated with Staphylococcus aureus and without Lactobacillus fermentum has 3.90 log CFU of Staphylococcus aureus and the $\mathrm{pH}$ is 5.3 after 4 hours of incubation. Conversely, in the yoghourt contaminated with Staphylococcus aureus and to which Lactobacillus fermentum is added there is a total absence of Staphylococcus aureus with a similar value of $\mathrm{pH}$, i.e. 5.2 .

Inhibition of Staphylococcus aureus caused by the production of hydrogen peroxide must be excluded because Staphylococcus aureus has a catalase.

Competition for the amino acids in the milk medium cannot explain the inhibition of Staphylococcus aureus, because it grows in the milk without using aminoacids [14].

The capacity of Lactobacillus fermentum to produce bactériocines putrescine at summer evoked by Mikelsaar et al., so the inhibiting properties of Lactobacillus fermentum opposite Staphylococcus aureus rests on the production of the bactériocines [19].

\section{CONCLUSION}

Camel milk contains lactic acid bacteria possessing interesting inhibitory potential against pathogens (Staphylococcus aureus). This study was based on a lactic strain represented by Lactobacillus fermentum.
Its bioproducteurs effect of molecules which inhibit pathogens leaves a great debate on the use of these molecules in the pharmaceutical treatment of certain pathology and also in the agroalimentary sector.

\section{OUTSTRANDING PHRASES}

The addition of Lactobacillus fermentum isolated from camel milk has no inhibitory effect on yoghourt ferments

The decrease in the number of living cells of Staphylococcus aureus from the $3^{\text {rd }}$ hour of incubation in the presence of Lactobacillus fermentum shows the inhibitory effect of the latter.

Camel milk contains lactic acid bacteria possessing interesting inhibitory potential on pathogens (Staphylococcus aureus).

\section{REFERENCES}

[1] Yousef AE, Carolyn Carlstrom C. Food microbiology: a laboratory manual Wiley, 2003; p. 226. ISBN 9780471391050 .

[2] Siboukeur O. Etude du lait camelin collecté localement: caractéristiques physico-chimiques et microbiologiques; aptitudes à la coagulation. Thèse doctorat, Institut National Agronomique El-Harrach - Alger (Algérie) 2008; p. 135.

[3] De Vrese M, Stefelmann A. Probiotics-compensation for lactase insufficiency. Am J Clin Nutr 2001; 73: 421S-29S.

[4] Heyman M. Effect of lactic acid bacteria on diarrheal diseases. J Am Coll Nutr 2000; 19: 137S-46S.

[5] Meydani SN, Ha W-K. Immunologic effects of yogurt. Am J Clin Nutr 2000; 71: 861-72.

[6] Wang K-Y, Liu C-S. Effects of ingesting Lactobacillus- and Bifidobacterium-containing yogurt in subjects with colonized Helicobacter pylori. Am J Clin Nutr 2004; 80: 737-41.

[7] Jacqmain M, Doucet E. Calcium intake, body composition, and lipoprotein-lipid concentrations in adults. Am J Clin Nutr 2003; 77: 1448-52

[8] Fédération Internationale du Lait., Lait et produit laitiers, Préparation des échantillons et des dilutions en vue de l'examen microbiologique. Document 122C.

[9] Karam NE, Karam $H$. Isolement et caractérisation de bactéries lactiques de laits crus d'Algérie. In: Alimentation génétique et santé de l'enfant, Eds J.F. Desjeux et $M$. Touhami, L'Harmattan. 1994; pp. 257-264.

[10] Petransxiene P, et Lapied L. Qualité bactériologique du lait et des produits laitiers : Analyse et tests. 2ème édition, Tech et Doc Lavoisier, Paris 1981; pp. 44-81.

[11] Guiraud JP. Microbiologie alimentaire. Technique et Ingénierie. Série Agroalimentaire, Eds. Dunod, Paris 1998; p. 652.

[12] Tadesse G, Ephraim E. et Ashenafi M. Assessment of the antimicrobiol activity of lactic acid bacteria isolated from borde of Shamita, traditional Ethiopian fermented beverage, on some food borne pathogens and effect of growth medium in the inhibitory activity. Food Safety 2004; 5: 13-20.

[13] Anas M, Rizk HA, Eddine HJ, Ahmed K, Mebrouk K. Antibacterial activity of Lactobacillus plantarum isolated from Algerian raw gaot's milk against Staphylococcus aureus. Les technologies de laboratoire 2010; Vol 5(21): pp. 26-33. 
[14] Alomar J, Loubiere P, Delbes C, Nouaille S, Montel MC. Effect of Lactococcus garvieae, Lactococcus lactis and Enterococcus faecalis on the behaviour of Staphylococcus aureus in microfiltred milk (Food Microbiology, en revisión) 2007.

[15] Bergey's Manual of Systematic Bacteriology. Williams \& Wilkins, Baltimore 1986; Vol. 2: pp. 1208-1234.

[16] AFNOR. Produits laitiers frais - Spécifications des laits fermentés et des yaourts/yoghourts. Paris, Janvier 2001: NF V04-600
[17] Gunter K, Pack A, Bonaparte C, Reute G. Taxonomy and physiology of probiotic lactic acid bacteria. J Food Microbiol 1998; 41: 103-25.

[18] Karam NE. Constitution d'un souchier de bactéries lactiques à intérêt biotechnologique: Etude Biochimique et Moléculaire. Thèse de Doctorat d'état, Université d'Oran. Algérie 1995.

[19] Marika M, Zilmer M. Lactobacillus fermentum ME-3 An antimicrobial and antioxidative probiotic. Microbial Ecol Health Disease 2009; 21(1): 1-27.

http://dx.doi.org/10.1080/08910600902815561 